\title{
CONSENSUS AND CONTRARIANISM ON CLIMATE CHANGE HOW THE USA CASE INFORMS DYNAMICS ELSEWHERE
}

\author{
MAXWell T. BOYKOFF
}

\begin{abstract}
Against a contrasting backdrop of consensus on key issues on climate science, a heterogeneous group dubbed climate «skeptics», "contrarians», «deniers» have significantly shaped contemporary discussions of climate science, politics and policy in the public sphere. This essay focuses on the USA context, and explores some of the intertwined social, political and economic factors, as well as cultural and psychological characteristics that have together influenced public attitudes, intentions, beliefs, perspective and behaviors in regards to climate change science and governance over time. This article makes the case that the USA example can inform developments elsewhere; as such it is important to consider these contextual elements to more capably appraise «contrarian», «skeptic», «denier» reverberations through the current public discussions on climate change.
\end{abstract}

Keywords: consensus, skepticism, contrarianism, climate change, public opinion.

In September 2014, United States President Barack Obama delivered a speech at the United Nations Climate Summit regarding the seriousness of climate change and the need to take action to address it. He stated: «There is one issue that will define the contours of this century more dramatically than any other. That is the urgent and growing threat of a changing climate... Nobody gets a pass [and] we will do our part...» (Mauldin \& Sparshott, 2014).

Immediately following his statement, many offered familiar laments about the chasm between scientific consensus that humans contribute to climate change and lack of policy action, fueled by obstructionist postures of those commonly referred to as climate «skeptics», «contrarians» or «deniers». These outlier perspectives have been identified in various ways, from shills of carbon-based industry interests to politicians (e.g. US Congressional Republicans), renegade academics or «hobbyists» (Dunlap, 2013; Victor, 2014).

For example, US Environmental Protection Agency (EPA) Chief Gina McCarthy argued that action should be taken not «despite the economy» but «because of it», forcefully adding that it was «sad» that climate contrarians «hide behind the word "economy" to protect their own special interests» (Barron-Lopez, 2014). As another example, US Senator Bernie Sanders commented: «This is a crisis and we've got [to] address it. The bad news is that Republicans in Congress, many of whom don't even believe the scientific consensus that global warming is a growing threat to our planet, continue to block legislation to address the planetary crisis» (Cox, 2014).

At first glance, one may choose to dismiss this dissonance as noise in the system. Holding firm to indefensible «do-nothing» positions given the overwhelming evidence that humans are contributing to climate change, and that the impacts are tremendous (Field, Barros, Mach, \& Mastransrea, 2014) can be seen as foolish. However, taking these dissenting views into account through more measured consideration reveals the many different 
cultural, political, economic, psychological and social elements to these discursive stances that make it more challenging to simply «name, shame and blame» the individual or collective culprits for the positions they take up (let alone get them to change). This article focuses on the USA case, where «skepticism», «contrarianism», and «denialism» have been seen to be particularly evident, from the halls of federal government (e.g. US Congress) to everyday US citizens. However, it is a mistake to think of these issues as merely anomalous US American challenges: these are cultural, political, economic, psychological, and social elements that pervade perceptions and decision-making on climate change elsewhere. This article consequently makes the case that interrogations of consensus and skepticism on climate change in the USA can help inform considerations of consensus and skepticism on climate change in other political and cultural contexts elsewhere (e.g. Spain, France, UK, Australia, India, China, Japan).

\section{SKEPTICISM, CONTRARIANISM, DENIAL}

In various ways, skeptics, contrarians or deniers have worked to counter efforts seeking to mobilize public action on climate challenges. Over time, researchers have sought to develop more exacting definitions of these groups in order to provide greater texture to the motivations of their work and the implications of their varied influences regarding climate change.

Many mention that skepticism forms an integral and necessary element of scientific inquiry. However, its use to describe outlier views on climate change has been less positive, often because the skepticism derived from ideology is often prominent over skepticism derived from scientific evidence. The term skeptic has been most commonly invoked to describe someone who dismisses the scientific evidence that climate change is a problem and that humans, in part, contribute to the problem. Considering contrarians, Aaron McCright (2007) has defined climate contrarians as those who vocally challenge what they see as a false consensus of mainstream climate science through critical attacks on climate science and eminent climate scientists, often with substantial financial support from fossil fuels industry organizations and conservative think tanks. Saffron O'Neill and I further developed a definition of «climate contrarianism» by disaggregating claims-making to include ideological motives behind critiques of climate science, and exclude individuals who are thus far unconvinced by the science or individuals who are unconvinced by proposed

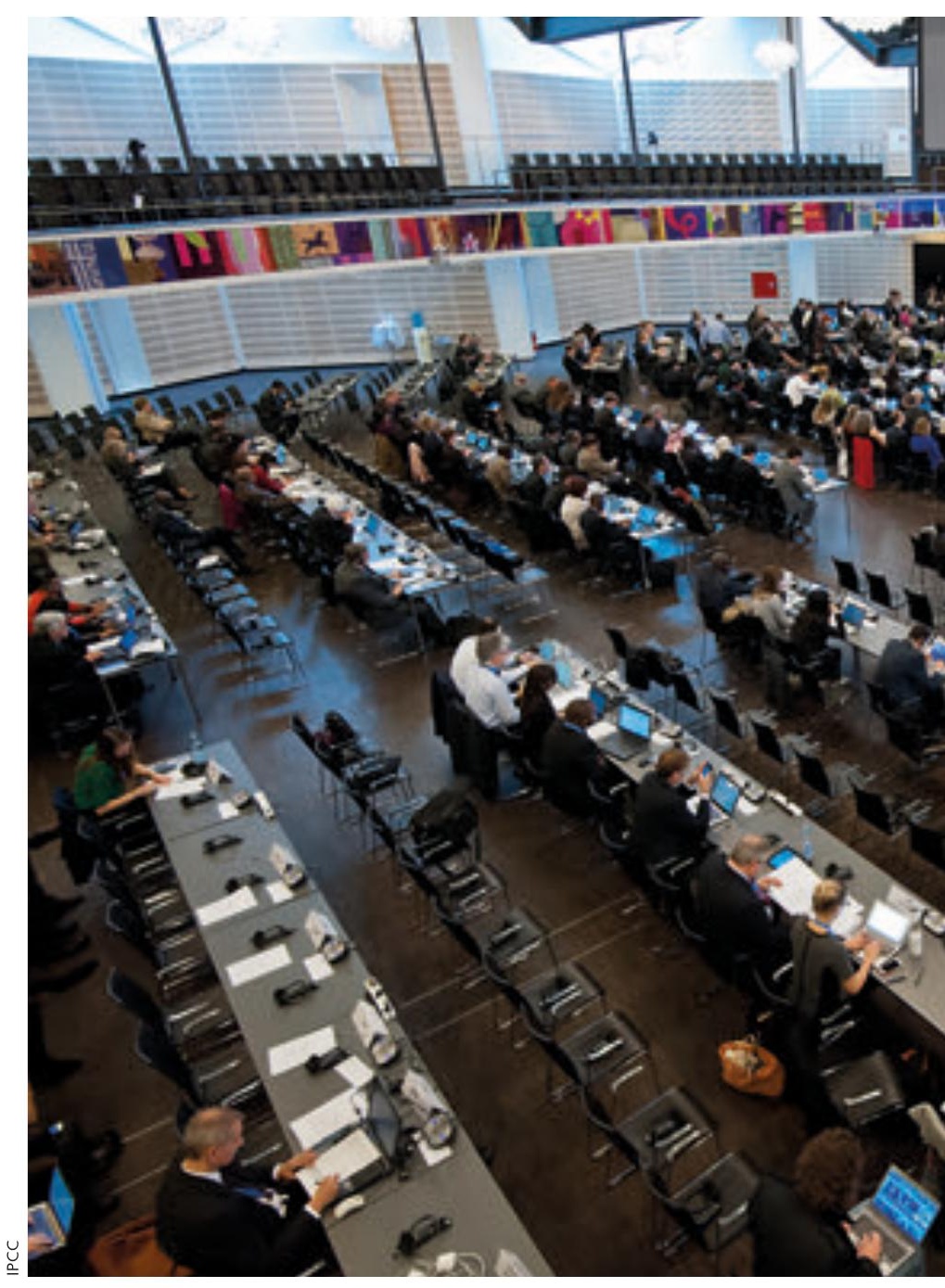

In various ways, skeptics, contrarians or deniers have worked to counter efforts seeking to mobilize public action on climate challenges. In the picture, IPCC meeting in Copenhagen, October 2014.

\author{
"DEEPLY ENTRENCHED SKEPTICISM \\ REGARDING SCIENTIFIC CLAIMS \\ OF ENVIRONMENTAL DECLINE HAS BEEN \\ EVIDENT FOR MANY CENTURIES»
}




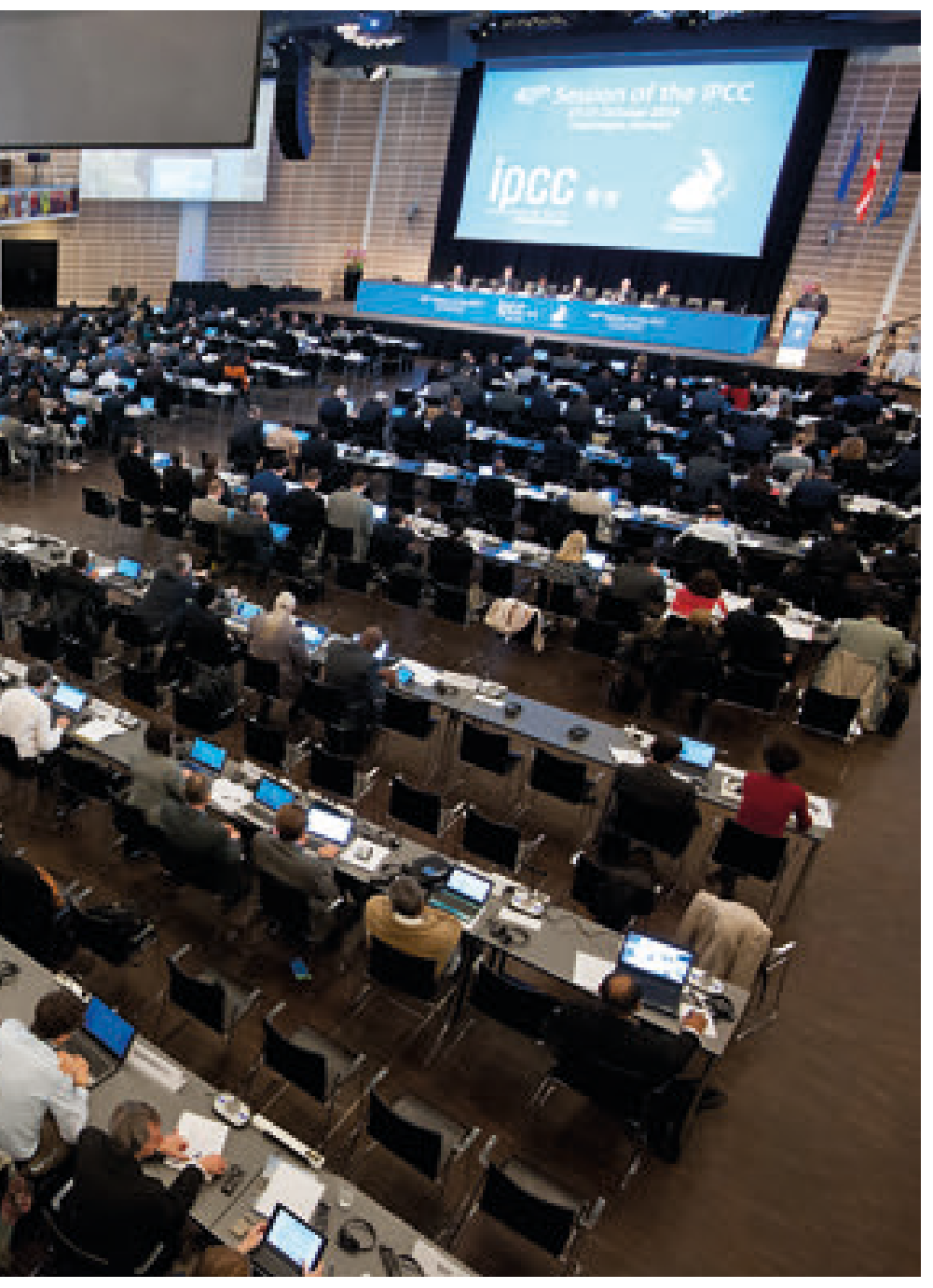

solutions, as these latter two elements can be more usefully captured through different terminology (O’Neill \& Boykoff, 2010). Meanwhile, Kari Marie Norgaard (2006) has focused on the aspect of denial, and has developed three dimensions as they relate to environmental issues: literal (sheer refusal to accept evidence), interpretative (denial based on interpretation of evidence) and implicatory (denial based on the change/response that acceptance would necessitate). The use of the term denier (or its variant denialist) has been criticized for its unnecessary and inappropriate implicit link to other movements of denial; nonetheless this is a term that has gained traction in popular discussion.

Taken together, these efforts have sought to provide greater texture to the motivations behind, and implications of expressions of skepticism, contrarianism and denial regarding climate change. In common parlance in the public arena, invocations of these terms have been overlapping. And while skepticism and denialism have been often favored terms invoked in the public arena to describe ideological - rather than scientific - contention, 'contrarianism' is seen to be the most accurate and least inflammatory way to do so.

Political economic interests can be seen as a frequent motivator behind skeptical, contrarian, or denialist/denier statements made on climate change, and these are not to be overlooked (Oreskes \& Conway, 2010). For example, as Charles and David Koch question the fundamentals of whether the climate is changing or whether humans play a role in climate change - taking up outlier views far from those of relevant expert science communities on these issues - they can also be seen to align themselves with right-wing think tanks like Americans for Prosperity in order to protect their over $\$ 40$ billion in oil and gas assets and interests that could face threats from climate-related regulations (Mayer, 2010).

Yet, adding to these political economic motivations, important cultural characteristics and psychological factors are also intertwined, together influencing underlying attitudes, intentions, beliefs, perspective, and behaviors in regard to climate change science and governance. For example, in 2009 the American Psychological Association took up the interdisciplinary task of examining and articulating these connections in a report Psychology and Global Climate Change. Their stated entry point into the topic was that climate change is an issue «not easily detected by personal experience, yet it invites personal observation and evaluation» (Swim et al., 2009, p. 1). Dan Kahan has continued to examine these dimensions through cultural cognition, where people's perceptions are found to be shaped largely by their values and by their role models (Kahan, JenkinsSmith, \& Braman, 2010).

\section{THE ROOTS OF ENVIRONMENTAL SKEPTICISM}

Looking at this historically, deeply entrenched skepticism regarding scientific claims of environmental decline has been evident for many centuries, as demonstrated in British colonial documentation. In the first half of the nineteenth century, numerous members of the scientific community - mainly botanists and doctors - warned governments in the UK and the colonial periphery about the dangers of damaging ecosystem services during this process of 'taming' the wild and migrating to new parts of the planet. Although British government officials were responsive to immediate 
and major crises - such as a famine or drought - these creeping environmental challenges were given very low priority (Rajan, 2006). Often, with the passage of the immediate crisis, civil administrators would raise skeptical objections about the claims of the scientists regarding environmental decline. For example, Robert Baden-Powell - a lieutenant general in the British Army and colonial forestry advocate - observed: «In the official mind up to the highest, we find various degrees of disinclination towards vigorous conviction: and just as we find in the people the progress of conviction barred by self-interest, so is it with their rulers. Considerations of interest, such as the desire to have no complaints and have everything snug and quiet in the district, to show a good revenue sheet by yielding forest produce... affect their capacity for the reception of a sure belief in forest economy» (Rajan, 2006, p. 235). Thus, this skepticism stemmed not merely from skepticism regarding scientific evidence of the decline of ecosystem services, but also from the implications that such a decline had for ongoing, unfettered colonial expansion and capitalist exploitation of resources for profit.

These roots and shoots of skepticism regarding scientific evidence and skepticism emergent from ideology, spread through many associated environmental issues (like climate change) in contemporary spaces and places. For example, in the USA variants of dissent - described through climate skepticism, contrarianism and denial - have pervaded and often polarized politics, culture and society (Oreskes \& Conway, 2010). Recognizing roots connected to British colonization, US-strains of climate contrarian movements developed from a wider historical context of conservatism mapping onto antienvironment stances that took hold in the late 1960s and '70s, around the time of a wave of progressive environmental legislation in the United States. Among resistance movements were the Sagebrush Rebellion and the Wise Use movement, which, under the direction of charismatic and well-connected leaders, sought to reform public land management with privatised decision-making and rights (Dunlap $\&$ McCright, 2011). Yet in the mid to late 1980s, in the context of Reaganomics and corollary efforts to reduce the regulatory power of the EPA and the Department of the Interior, climate contrarianism became articulated in full form as anti-regulatory and anti-environmental, and neoliberal environmental movements emerged in the public arena. These historical and cultural interactions spawned the cynical term «wise contrarians» to describe those who have populated the public sphere and have drawn

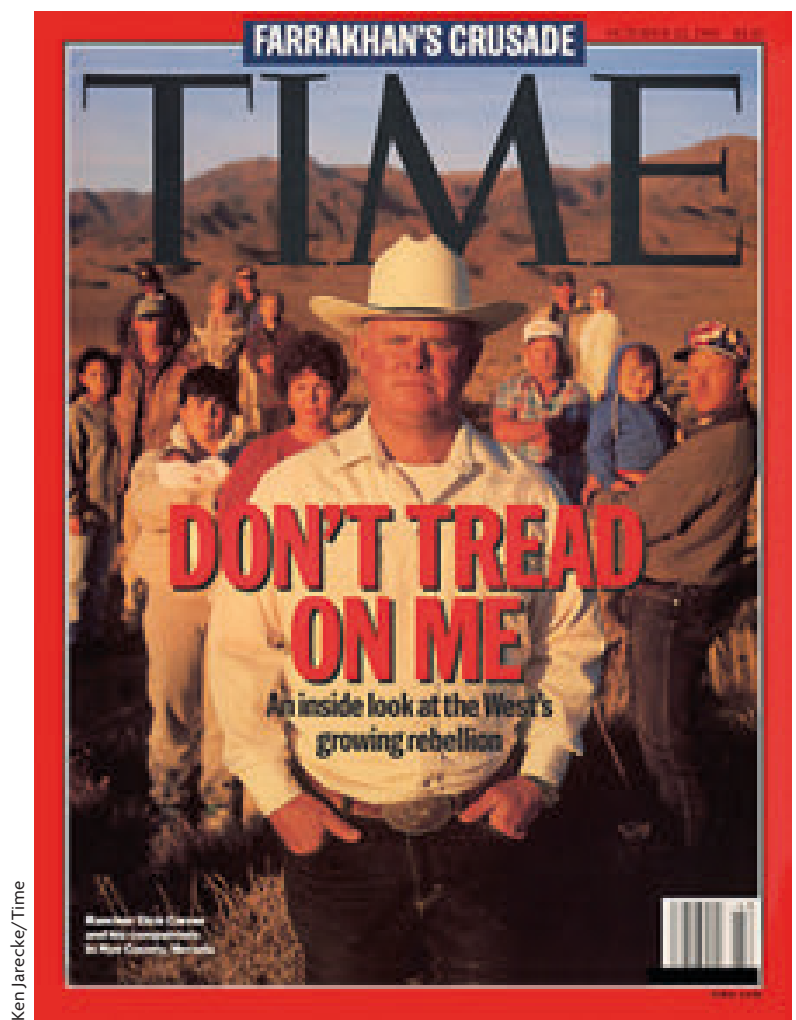

Resistance movements such as the Sagebrush Rebellion and the Wise Use movement sought to reform public land management with privatised decision-making and rights, generally under the direction of charismatic and well-connected leaders. In the image, cover of Time (23 October 1995) picturing the farmer Dick Carver, considered one of the instigators of the second Sagebrush Rebellion.

"IN THE MID TO LATE 1980S, CLIMATE CONTRARIANISM BECAME ARTICULATED IN FULL FORM AS ANTI-REGULATORY AND ANTI-ENVIRONMENTAL, AND NEOLIBERAL ENVIRONMENTAL MOVEMENTS EMERGED IN THE PUBLIC ARENA» 
from historical influences from Wise Use movements (Boykoff \& Olson, 2013). These amplified views have been seen to be a reflection of right-of-center perspectives amid a complex mix of contemporary cultural politics. As such, the Republican Party platform of 2012 articulated a repudiation of Agenda 21 - developed at the 1992 United Nations Rio Summit that was considered the blueprint for sustainable development in the coming century through newfound suspicions of global governance in order to fuel long-standing distaste for regulatory intervention at all levels (Boykoff \& Olson, 2013). Moreover, as neoliberal and utilitarian ideologies mapped out onto carbon-based industry interests, they also adhered themselves to US Republicanism, skepticism, contrarianism, and denialism. Some see this as a toxic mix that pollutes considerations of this form of international environmental cooperation. And, these resistances all feed quite nicely - for those opposing US government action - into efforts that seek to muddy the waters of decision-making on climate change.

Research by Riley Dunlap and Aaron McCright (2011) has focused on these opposition movements in the US, and has examined how certain individuals worked - at times through media attention - to develop competing discourses that disempowered top climate science during the Newt Gingrich-led «Republican revolution» of 1994 to effectively gain a foothold in national and international discourse on the causes of climate change. Such efforts have also continued to receive support from the US Chamber of Commerce, which hired lobbyists and spent millions of dollars on advertising contrarian views about climate science and policy. The US Chamber of Commerce has received contributions from numerous carbonbased industry groups over past decades to help fight climate legislation and question scientific understanding of the issues. Robert Brulle (2014) has traced carbon-based industry funding through a complex network of groups such as Donors Trust, to identify how certain skeptical, contrarian, and denialist voices are amplified in the public arena.

Moreover, many contrarian initiatives in the US have been tied to carbon-based industry funding sources. For example, there has been the ${ } \mathrm{CO}_{2}$ is Green» advertising campaign, launched in the summer of 2010. Running in The Washington Post, the advert was a piece of an ongoing larger campaign by a group bearing the same name. In their words: «Our mission is to support scientifically and economically sound public policy on environmental issues. Currently, we are especially concerned with federal proposals that would interfere with nature's dependence on carbon dioxide $\left(\mathrm{CO}_{2}\right)[\ldots] \mathrm{CO}_{2}$ is Green is working to insure that all federal laws or regulations are founded upon science and not politics or scientific myths» $\left(\mathrm{CO}_{2}\right.$ is Green, 2010). The group sought to contest the notion that carbon dioxide $\left(\mathrm{CO}_{2}\right)$ is a pollutant, and thus protest legislation that aimed to mitigate $\mathrm{CO}_{2}$ emissions. These particular claims were enabled through financial backing by coal interests, in particular H. Leighton Steward (Mulkern, 2010). His documented carbonbased industry career has also been punctuated by his role as Chair of the US Oil and Gas Association and the Natural Gas Supply Association, and as an honorary Director of the American Petroleum Institute (Mulkern, 2010). While far from universal, $\mathrm{CO}_{2}$ is Green can be seen as a representative skeptic/ contrarian/denier endeavor where asymmetrically powerful «astroturf» groups rail against the «climate establishment» and where highly sophisticated and rapidly adaptive campaigns often seek to protect vested interests.

\section{CLIMATE CHANGE IN THE PUBLIC SPHERE}

Against a contrasting backdrop of consensus on key issues on climate science, a heterogeneous, yet loosely configured group of people dubbed climate «skeptics», «contrarians», or «deniers» have now achieved veritable «celebrity status» in contemporary discussions of climate science, politics and policy in the twenty-first century public sphere (Boykoff \& Olson, 2013). While it may also be tempting to dismiss such skeptical, contrarian or denialist efforts as isolated, fringe, anomalous, or geographically specific, they actually represent one of many contested spaces in the larger battlefield of decisionmaking regarding global political economy and energy production as well as public engagement with climate change. 
Moreover, when contrasting these views with notions of consensus, and when casting these perspectives as «outliers», it may be tempting to assemble a taxonomy of contrarianism, skepticism or denialism. However, this approach runs multiple risks. Among them is the risk of overlooking the context through overemphasis on the individual as locus of agency. It can be a mistake to focus on the claims-makers at the sacrifice of critical consideration of the claims they make. Blanket assertions of climate skepticism, denialism or contrarianism across a range of distinct science and governance issues, risks rejecting potentially legitimate and useful critiques out of hand by way of dismissing the individual rather than the arguments put forward. Treatment of individuals through (often

\section{"THROUGH THE PROCESS OF NAMING, SHAMING AND BLAMING THE OTHER, THERE IS A TENDENCY TO OVERLOOK COMMON RESPONSIBILITIES ASSOCIATED WITH ANTHROPOGENIC CLIMATE CHANGE"}

demonizing) labels may work to identify «outliers», but may fail to shine a light on the contours of their problematic arguments.

It can also be a mistake to excessively focus on individual personalities at the cost of critically considering political, economic, social, psychological and cultural forces at work. In other words, challenges arise when the gaze on the individual claimsmakers subsumes deeper structural or institutional questions. Jo Littler (2009) has commented that the political economic and societal dimensions can often be lost when the focus is on atomized alternatives for action. This has also been referred to as a shift to «responsibilisation», where climate change becomes the responsibility of the individual in place of governments or regulators who might affect significant policy changes through altering production and distribution (Littler, 2009). In the case of climate change, highly individualized scrutiny meshes with highly individualized ways to take action (e.g. changing lightbulbs, turning off lights, recycling etc.). Other scholars have posited that this shift toward a focus on arguing personalities is part of larger movements in a «new green order» where commodified and highly-individualized solutions

\section{Urge Your Senators to Vote "No" to the President's Cap-and-Trade Bill that will increase your cost of living and not change the climate}

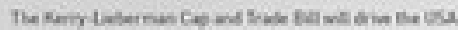

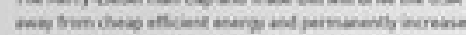

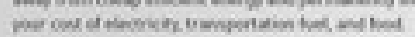

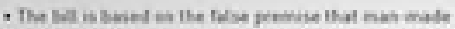

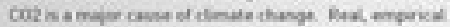

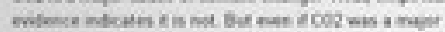

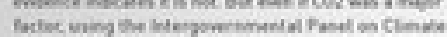

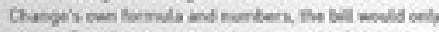

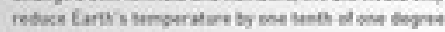
mein Benest wi wern

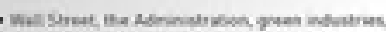

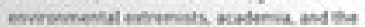
mest mil be Kerry Lipberman you wall

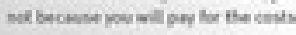

- Proneg Karn-Letermen well sot dive the of spet. Cont at the seill wat be

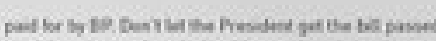

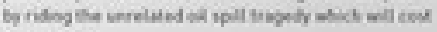
you monery

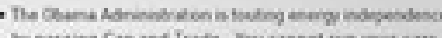

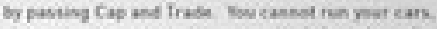

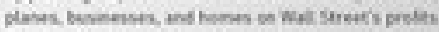
Wind asd Selar provide less than eece pervent ef eer eneingy and but with nut eccreme by a measinglat

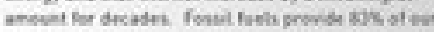

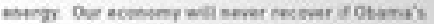
fivat en this intertry serretet

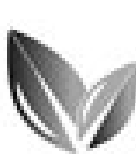

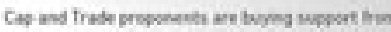

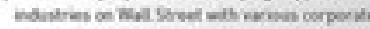
gnewen in he det wes the wry experose

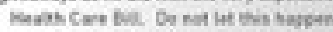

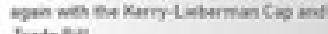

\section{$\mathrm{CO}_{2}$ IS GREEN}

Do understand CO\&'s negtigible impact on climate change, go to COeisgreen.org

Keep America Strong. Protect jobs.

Defeat the Kerry-Lieberman Cap-and-Trade Bill.

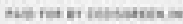

Above, the " $\mathrm{CO}_{2}$ is Green" advertising campaign, launched in the summer of 2010 in The Washington Post. The group seeks to contest the notion that $\mathrm{CO}_{2}$ is a pollutant and protest against legislation aimed to mitigate carbon dioxide emissions. Below, a promotional video from its YouTube channel.

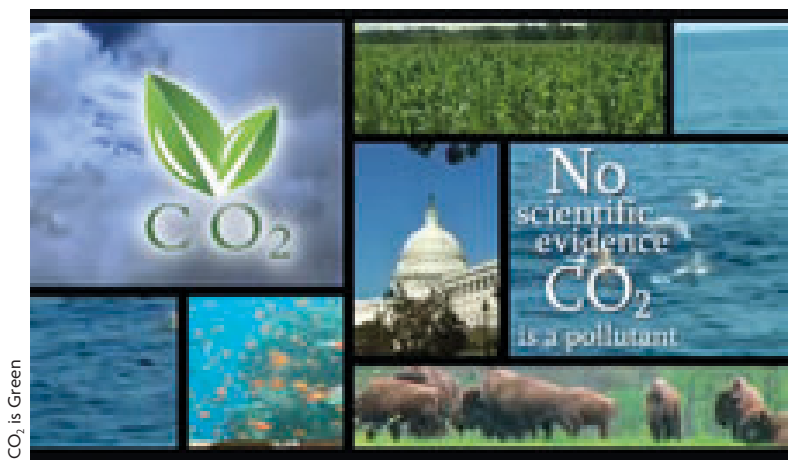

"MANY CONTRARIAN INITIATIVES IN THE US HAVE BEEN TIED TO CARBONBASED INDUSTRY FUNDING SOURCES. FOR EXAMPLE, THE "CO $\mathrm{CO}_{2}$ IS GREEN" ADVERTISING CAMPAIGN» 
are seen to actually move citizens further away from considering their role in requisite collective institutional shifts towards decarbonization. Together, these trends and foci can serve to distract citizens from the scale of the challenges associated with contemporary climate change, and from more textured dimensions of institutional analysis of how climate science and governance interact, as well as contestation therein.

Another key risk is that through the process of naming, shaming and blaming the «other», there is a tendency to overlook common responsibilities associated with anthropogenic climate change. As we collectively hurtle through the new millennium, the complex and multi-faceted issue of climate change is an issue that cuts to the heart of our human relationship with the environment. It cuts to the heart of how we live, work, play and relax in modern life, and thus critically shapes our everyday lives, lifestyles and livelihoods. To the extent that naming, shaming and blaming distracts from their common responsibilities, it then often actually serves the interests of the named, shamed and blamed.

Therefore, when considering the contrasts between consensus and skepticism on climate change, it is critically important to remain mindful of the importance of context, as well as the dangers of excessive focus on those dubbed «skeptics», «contrarians» or «deniers». Moreover, what happens regarding debates and discussions of consensus and skepticism in the USA, does not merely stay in the USA; instead, it pervades ongoing discourses in other cultural and political contexts. Overall, if excessive attention to unfounded dissent narrows, rather than widens a spectrum of possible considerations of the full scope of diagnoses and prognoses, course corrections are in order.

\section{REFERENCES}

Barron-Lopez, L. (2014, September 25). EPA chief: Climate skeptics "sad". The Hill. Retrieved from http://links.uv.es/02RkAVH

Boykoff, M., \& Olson, S. (2013). "Wise contrarians" in contemporary climate science-policy-public interactions. Celebrity Studies Journal, 4(3), 276-291. doi: 10.1080/19392397.2013.831618

Brulle, R. (2014). Institutionalizing delay: Foundation funding and the creation of U.S. climate change counter-movement organizations. Climatic Change, 122(4), 681-694. doi: 10.1007/s10584-013-1018-7 Cox, R. (2014, September 24). Sanders blasts GOP climate change deniers. The Hill. Retrieved from http://links.uv.es/Z64xdbM
$\mathrm{CO}_{2}$ is green (2010, January 19). More $\mathrm{CO}_{2}$ results in a greener Earth: About us. Co2isgreen.org. Retrieved from http://links.uv.es/78Hnpcq on 2014 , October

Dunlap, R. E. (2013). Climate change skepticism and denial: An introduction. American Behavioral Scientist 57(6), 691-698. doi: 10.1177/0002764213477097

Dunlap, R. E., \& McCright, A. M. (2011). Organized climate change denial. In J. Dryzek, R. Norgaard, \& D. Schlosberg (Eds.), The Oxford handbook of climate change and society. Oxford: Oxford University Press.

Field, C. B., Barros, V. R., Mach, K. J., \& Mastransrea, M. D. (Coords.). (2014). Technical summary. In C. B. Field, V. R. Barros, D. J. Dokken, K. J. Mach, M. D. Mastrandrea, T. E. Bilir, ...L.L. White (Eds.), Climate change 2014: Impacts, adaptation, and vulnerability. Part A: Global and sectorial aspects. Contribution of Working Group II to the Fifth Assessment Report of the Intergovernmental Panel on Climate Change. Cambridge \& New York: Cambridge University Press.

Kahan, D. M., Jenkins-Smith, H., \& Braman, D. (2010). Cultural cognition of scientific consensus. Journal of Risk Research, 9(2), 1-28. doi: 10.2139/ssrn.1549444

Littler, J. (2009). Radical consumption: Shopping for change in contemporary culture. London: Open University Press.

Mauldin, W., \& Sparshott, J. (2014, September 23). Obama: U.S., China must lead on climate change efforts. Wall Street Journal. Retrieved from http://links.uv.es/T0dC3vP

Mayer, J. (2010, August 30). Covert operations: The billionaire brothers who are waging a war against Obama. The New Yorker.

McCright, A. M. (2007). Dealing with climate contrarians. In S. C. Moser, \& L. Dilling (Eds.), Creating a climate for change: Communicating climate change and facilitating social change. Cambridge: Cambridge University Press.

Mulkern, A. C. (2010, August 17). Oil group, climate bill supporters clash in summer campaigns. New York Times Greenwire. Retrieved from http:// links.uv.es/qz5FnD0

Norgaard, K. M. (2006). "People want to protect themselves a little bit": Emotions, denial, and social movement nonparticipation. Sociological Inquiry, 76(3), 372-396. doi: 10.1111/j.1475-682X.2006.00160.x

O'Neill, S. J., \& Boykoff, M. (2010). Climate denier, skeptic or contrarian? Proceedings of the National Academy of Sciences, 107, E151. doi: 10.1073/pnas.1010507107

Oreskes, N., \& Conway, E. M. (2010). Merchants of doubt: How a handful of scientists obscured the truth on issues from tobacco smoke to global warming. New York: Bloomsbury Press.

Rajan, S. R. (2006). Modernizing nature: Forestry and imperial ecodevelopment 1800-1950. Oxford: Oxford University Press.

Swim, J., Clayton, S., Doherty, Th., Gifford, R., Howard, G., Reser, J., ...Weber, E. (2009). Psychology and global climate change: Addressing a multi-faceted phenomenon and set of challenges. Washington: American Psychological Association. Retrieved from http://links.uv.es/0CPx8rd

Victor, D. (2014, January 8). Global warming denialism: What science has to say - Introduction and documentary video about the people associated with global warming denial. Lecture at the Scripps Institution of Oceanography, UC San Diego. Retrieved from http://links.uv.es/ hS6TO3R

Maxwell Boykoff. Fellow in the Cooperative Institute for Research in Environmental Sciences (CIRES) as well as an Associate Professor in Environmental Studies at the University of Colorado-Boulder (USA). His research and creative work focuses on cultural politics and environmental governance, creative climate communications, science-policy interactions, disaster risk reduction and climate adaptation. 